\title{
Prediksi Asam Kuinat Sebagai Anti-Inflamasi Terhadap COX-2 Secara Virtual
}

\section{Virtual Prediction of Quinic Acid As Anti-Inflammation of COX-2}

\author{
Yohanes Bare ${ }^{1 *}$, Agustina Dua Kuki ${ }^{2}$, Apriani Herni Rophi ${ }^{3}$, Gabriella Candrakirana \\ Krisnamurti $^{4}$, Margaretha Rika Wahyu Gabrella Lorenza ${ }^{5}$, Dewi Ratih Tirto Sari ${ }^{6}$ \\ ${ }^{1}$ Program Studi Pendidikan Biologi, Fakultas Keguruan dan Ilmu Pendidikan, Universitas Nusa Nipa, \\ Nusa Tenggara Timur, Indonesia \\ ${ }^{2}$ Program Studi Pendidikan Kimia, Fakultas Keguruan dan Ilmu Pendidikan, Universitas Nusa Nipa, \\ Nusa Tenggara Timur, Indonesia \\ ${ }^{3}$ Program Studi Pendidikan Biologi, Fakultas Keguruan dan Ilmu Pendidikan, Universitas Cendrawasih, \\ Papua, Indonesia \\ ${ }^{4}$ Biotechnology Program, School of Bioresources and Technology, King Mongkut's University of Technology \\ Thonburi, Thailand \\ ${ }^{5}$ Life Science Department, College of Health Science and Technology, National Central University, Taiwan \\ ${ }^{6}$ Jurusan Biologi, Fakultas Matematika dan Ilmu Pengetahuan alam, Universitas Brawijaya, Kota Malang-Jawa \\ Timur, Indonesia \\ Email: bareyohanes@gmail.com \\ *Penulis Korespondensi
}

\begin{abstract}
Inflammation is a response against dangerous stimuli such as pathogens, damaged complicated, or irradiated cells. COX-2 is inflammatory mediators which plays a crucial role to increase inflammation. The anti-inflammatory immune system, which replaces mutations, increases inflammation. Therefore the natural bioactive is expected to decrease the inflamation. Quinic acid has very low toxicity and it does not have a negative effect on human organs. Quinic acid is the most potential drug for therapy. However just a little information about the compound. This research concerned to predict the potencyand to analyze quinic acid as an anti-inflammatory agent by inhibiting COX-2. The method used was by downloading the COX-2 protein from the protein data bank (PDB) and quinic acid were obtained from the PubChem database. Protein (COX-2) and ligand (quinic acid) were prepared with PyRx program. The analysis of protein and ligand binding was done by using the Hex program 8.0.0 and Discovery Studio Client 4.1. Associated protein and ligand showed positive results with finding two domain proteins bound with quinic acid. Protein A domain (GLU140, ASN144, SER143, and TRP139) and protein B domain (GLU236, THR237, LYS333, GLN241, GLN330, PHE329, and LEU238). The bond

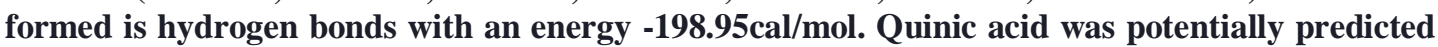
as an anti-inflammatory therapy; because there is a bond formed between the ligand and 11 amino acid residues.
\end{abstract}

Keywords:, anti-inflammatory, amino acid, quinic acid, COX-2, in silico, quinic acid, coffee

\begin{abstract}
Abstrak
Inflamasi merupakan mekanisme pertahanan tubuh terhadap terhadap rangsangan berbahaya, seperti patogen, sel-sel yang rusak, senyawa beracun, atau iradiasi. Selama inflamasi dalam tubuh terdapat COX-2 mediator inflamasi yang berperan meningkatkan inflamasi. Sistem imun anti-inflamasi yang mengalami mutasi menyebabkan inflamasi meningkat. Penggunaan bioaktif yang berasal dari alam di harapkan dapat menurunkan kondisi inflamasi. Asam kuinat memiliki toksisitas yang sangat rendah dan tidak memberikan efek negatif terhadap organ tubuh manusia. Asam kuinat memiliki potensi yang besar sebagai kandidat obat tertinggi dalam terapi. Penelitian ini bertujuan unutk memprediksi potensi serta menganalisis asam kuinat sebagai agen inflamasi dengan cara menghambat COX-2. Metode yang digunakan ialah metode in silico. Pengunduhan protein COX-2 dari protein data bank (PDB) dan asam kuinat diperoleh dari database PubChem. Persiapan protein (COX-2) dan ligan (asam Kuinat) dengan program PyRx, analisis interaksi protein dan ligan menggunakan program Hex 8.0.0 dan Discovery Studio Client 4.1. Interaksi antara protein dan ligan menunjukan hasil positif dengan ditemukan 2 domain protein yang berikatan dengan asam kuinat. Protein domain A (GLU140, ASN144, SER143, dan TRP139) dan protein domain B (GLU236, THR237, LYS333, GLN241, GLN330, PHE329, dan LEU238). Ikatan yang terbentuk yaitu ikatan hidrogen dengan energi sebesar $-198.95 \mathrm{cal} / \mathrm{mol}$. Asam kuinat diprediksi memiliki potensi sebagai terapi anti-inflamasi, hal ini ditunjukan karena ada ikatan yang terbentuk antara ligan dan 11 residu asam amino.
\end{abstract}

Kata kunci: anti-inflamasi, asam amino, asam kuinat, COX-2, in silico, kopi

Diterima: 26 Agustus 2019 , disetujui: 13 September 2019 


\section{Pendahuluan}

Inflamasi adalah suatu respon sistem imunitas tubuh terhadap rangsangan berbahaya, seperti patogen, sel-sel yang rusak, senyawa beracun, atau iradiasi. Proses inflamasi yang terjadi merupakan mekanisme pertahanan yang utama bagi kesehatan dengan membentuk sitokin-sitokin maupun mediator yang bertanggung jawab dalam inflamasi (Chen et al., 2018; Medzhitov, 2010)

Ekspresi dari sitokin, mediator inflamasi berupa COX-2 dan pelepasannya ke dalam matriks ekstraseluler, menstimulasi perekrutan sel-sel imun lainnya. Aktivasi berlebihan sel-sel imun menyebabkan efek imunopatologis pada jaringan disekitarnya. Berbagai efek medis ditimbulkan seperti penyakit kardiovaskular (Libby, 2006), aterosklerosis (Libby, 2013), kanker, disertai dengan sistem kekebalan tubuh yang berlebihan (Coussens \& Werb, 2002; Schröter et al., 2019). Sistem imun merespon dengan melepaskan mediator sitokin antiinflamasi seperti IL-10 untuk menekan inflamasi yang yang terjadi di dalam tubuh. Akan tetapi penelitian Bare, Marhendra, Sasase, \& Fatchiyah, (2018) melaporkan pada saat inflamasi gen IL-10 mengalami mutasi pada organ lambung dan otak. Mutasi yang terjadi menyebabkan menurunkan kinerja IL-10 sebagai anti-inflamasi. Hal ini diperkuat dengan hilangnya beberapa pita protein yang diprediksi memiliki korelasi terhadap sistem imun dengan analisis SDS-PAGE (Bare \& Fatchiyah, 2018).

Pengurangan reaksi inflamasi dalam tubuh dilakukan dengan cara menghambat COX-2 sebagai mediator inflamasi yang berperan selama proses inflamasi. Aktivasi COX-2 akan menstimulus prostaglandin G2 menjadi prostaglandin $\mathrm{H} 2$ yang dapat meningkatkan inflamasi dalam tubuh (Kellogg, Pop-Busui, \& Cheng, 2008).

Penggunaan senyawa kimia berbahan alam merupakan solusi di dunia kesehatan, salah satunya adalah turunan dari tumbuhan yang diprediksi memiliki fungsi medis. Derivat tanaman yang sering digunakan adalah hasil metabolit sekunder yang dihasilkan seperti asam phenolik (Schröter et al., 2019). Penggunaan senyawa kimia yang berasal dari tanaman diharapkan dapat meminimalisir racun serta meningkatkan penyembuhan (Chaudhury et al., 2017; Kesuma, Siswandono, Purwanto, \& Hardjono, 2018).

Asam kuinat adalah salah satu golongan asam fenolik yang terkandung dalam biji kopi. Proses penyangraian yang dilakukan sebelum diseduh menyebabkan sebagian besar asam klorogenat terhidrolisis menjadi asam kuinat (Aziz, 2009; Farhaty, 2016; Higdon \& Frei, 2006; Yusianto \& Nugroho, 2014). Regulski et al., (2018) \& Shi et al., (2013) melaporkan bahwa asam klorogenat memiliki potensi untuk menghambat inflamasi studi in vitro and in vivo. Akan tetapi belum ada studi mendalam mengenai kandungan turunan dari asam klorogenat seperti asam kuinat. Studi Asam kuinat acute toxicity dan health effects menggunakan software MRDD menunjukan asam kuinat sebagai senyawa alam yang memiliki toksisitas yang sangat rendah dan tidak memberikan efek negatif terhadap organ tubuh manusia. Asam kuinat memiliki potensi yang besar sebagai kandidat obat tertinggi dalam terapi (Inbathamizh \& Padmini, 2013). Kurang kajian potensi asam kuinat sebagi agen antiinflamasi mendorong peneliti untuk mengkaji lebih lanjut. Tujuan dari penelitian ini adalah untuk menganalisis potensi asam kuinat sebagai agen anti-inflamasi dengan menghambat kinerja COX-2 mediator inflamasi melaui pendekatan in silico.

\section{Metode}

\section{Persiapan Ligan dan Protein}

Protein model COX-2 (ID:6cox) diperoleh dari pusat data Protein Data Bank (PDB) dengan alamat http://www.rcsb.org/pdb/home/home.do. Ligan asam kuinat diperoleh dari database PubChem.com (CID: 6508). Asam kuinat diminimalisir energinya menggunakan perangkat lunak PyRx virtual screening program Open Babel tool. Sedangkan Discovery Studio Client 4.1 digunakan untuk menghilangkan molekul air yang berikatan dengan COX-2. Perangkat lunak PyRx mengubah asam kuinat dari bentuk file SDF kedalam bentuk PDB format.

\section{Molecular Docking}

Proses interaksi ligan dan protein dilakukan dengan bantuan perangkat lunak moleculer docking HEX 8.0.0. Hasil docking divisualisasi dan dianalisis dengan bantuan perangkat lunak Discovery Studio Client 4.1. Analisis yang dikaji adalah interaksi yang terjadi berupa residu asam amino yang terikat dengan ligan, ikatan hidrogen dan energi ikatan yang terbentuk.

\section{Hasil dan Pembahasan}

Asam kuinat adalah merupakan komponen yang diekstrak dari tanaman obat termasuk Globula eucalyptus, Hymenocrater calycinus, Tara spinosa, Ageratina adenophora, Urtica dioica, biji kopi dan kulit kayu dari genus Cinchona (Zhang et al., 2018). 


\begin{tabular}{|lllll|}
\hline a. \begin{tabular}{llll|} 
Chemical \\
Compound
\end{tabular} & $:$ & $\begin{array}{l}\text { Asam } \\
\text { Kuinat }\end{array}$ \\
MW & $:$ & 192.17 & b. \\
LogP & $:$ & -2.3214 \\
Torque & $:$ & 1 & 5 \\
HBA & $:$ & 5 & \\
PSA & $:$ & 54.056 &
\end{tabular}

Gambar 1. a. Sifat fisikokimia asam kuinat menggunakan pkCSM online tool. MW = Molecular Weight $\operatorname{LogP}=$ logarithm of octanol/water partition coefficient; Torsion = a bond between atoms that can rotate; HBA = Hydrogen Bond Acceptors; HBD = Hydrogen Bond Donors; PSA = Polar Surface Activity; b. Struktur kimia asam kuinat (PubChem.com)

Sifat fisikokimia asam kuinat memiliki potensi sangat mudah diserap dan memiliki permeabilitas yang sangat tinggi. Hal ini sesuai dengan standar Lipinski et al., (1997). Berat molekul asam kuinat $192.17<500, \quad \log \mathrm{P}$ koefisien -2.3214<5; H-bond donor (HBD) $5=5$; dan $\mathrm{H}$-receptor bond (HBA) $5<10$

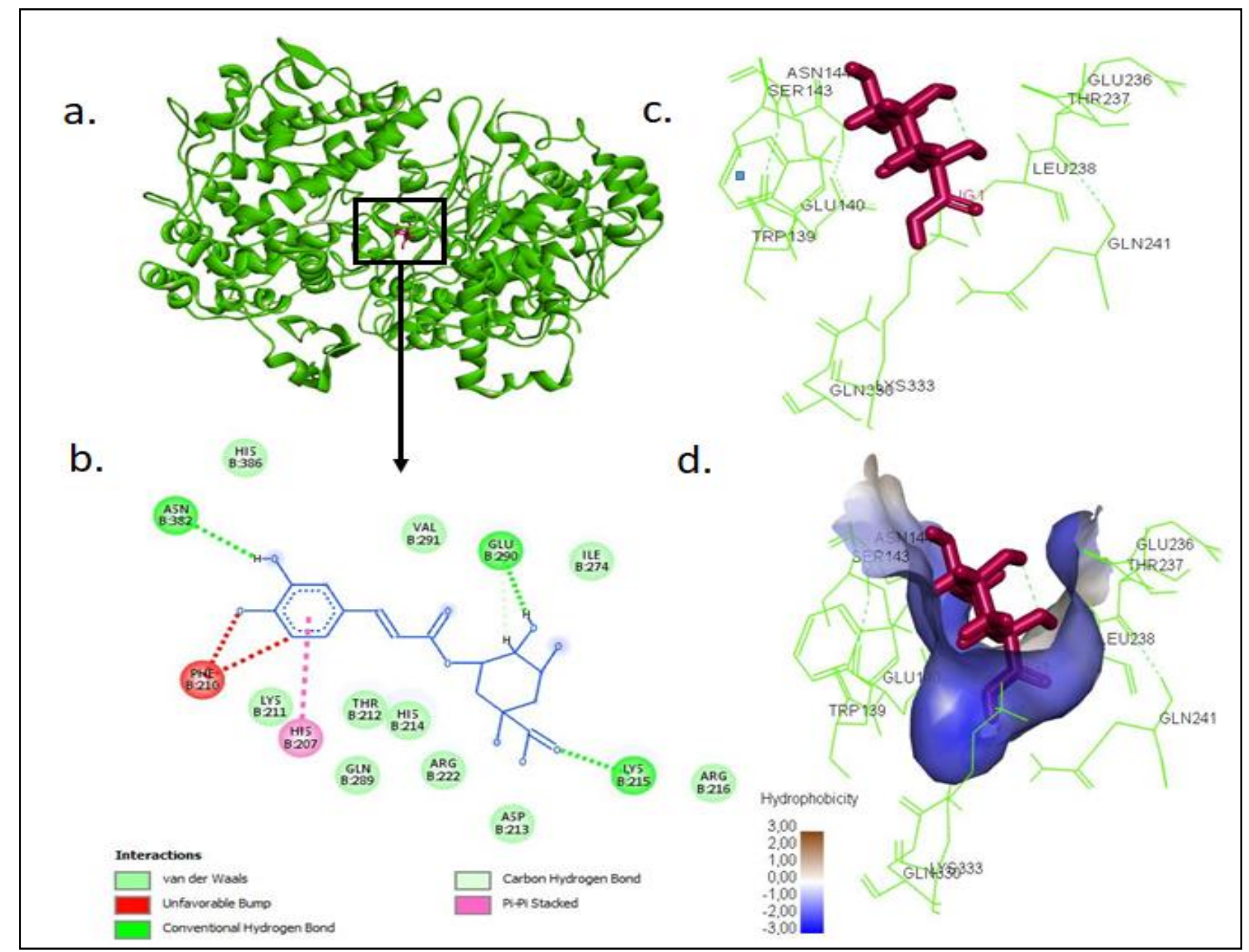

Gambar 2. Interaksi antara Asam Kuinat dan COX-2. a. Interaksi ligan dan Protein; b. Interaksi struktur 2D; c, Interaksi struktur 3D; d. Kompleks hydrophobicity (Dokumen pribadi, 2019)

Interaksi yang terjadi antara asam kuinat dan COX-2 menghasilkan sejumlah ikatan yang antar residu asam amino dengan asam kuinat. Ditemukan sebelas residu asam amino yang berinteraksi dengan asam kuinat dalam dua domain protein. Protein domain A yaitu: GLU140, ASN144, SER143, dan TRP139 sedangkan untuk protein domain $\mathrm{B}$ adalah 
GLU236, THR237, LYS333, GLN241, GLN330, PHE329, dan LEU238. Interaksi ligan dan residu asam amino GLU140, GLU236, GLN241 berupa ikatan hidrogen dengan tipe ikatan hidrogen konvensional. Delapan residu asam amino yang tersisa menunjukan adanya gaya van der waals yaitu residu asam amino ASN144, SER143, TRP139, THR237, LYS333, GLN330, PHE329 dan LEU238. Ligan dan protein yang berinteraksi memiliki energi ikatan sebesar $-198.95 \mathrm{cal} / \mathrm{mol}$. Ikatan hydrogen pada residu asam amino GLU236 memiliki ikatan yang sangat kuat jika dibandingkan dengan GLU140 dan GLN241. Hal ini disebabkan oleh ikatan hidrogen yang terbentuk akan menjadi sangat kuat jika jarak yang dihasilkan dari hidrogen menuju ke reseptornya semakin kecil (Santoso \& Atmajaya, 2016).

Tabel 1. Interaksi antara Asam Kuinat dan protein $C O X-2$

\begin{tabular}{|c|c|c|c|c|c|c|c|}
\hline Complexes & $\begin{array}{c}\text { Energy } \\
(\mathrm{cal} / \mathrm{mol})\end{array}$ & Name & Distance & Category & Types & $\begin{array}{c}\text { from } \\
\text { chemistry }\end{array}$ & $\begin{array}{c}\text { to } \\
\text { chemistry }\end{array}$ \\
\hline \multirow{5}{*}{$\begin{array}{l}\text { Quinic acid } \\
\text {-COX-2 }\end{array}$} & \multirow{5}{*}{-198.95} & $\begin{array}{c}\text { B:GLN241:HE21 } \\
- \text { :LIG1:O }\end{array}$ & 2.82557 & $\begin{array}{l}\text { Hydrogen } \\
\text { Bond }\end{array}$ & $\begin{array}{c}\text { Conventional } \\
\text { Hydrogen } \\
\text { Bond } \\
\end{array}$ & H-Donor & $\begin{array}{c}\text { H- } \\
\text { Acceptor }\end{array}$ \\
\hline & & $\begin{array}{c}\text { :LIG1:H - } \\
\text { A:GLU140:OE2 }\end{array}$ & 2.83181 & $\begin{array}{l}\text { Hydrogen } \\
\text { Bond }\end{array}$ & $\begin{array}{l}\text { Conventional } \\
\text { Hydrogen } \\
\text { Bond } \\
\end{array}$ & H-Donor & $\begin{array}{c}\mathrm{H}- \\
\text { Acceptor }\end{array}$ \\
\hline & & $\begin{array}{c}\text { :LIG1:H - } \\
\text { B:GLU236:O }\end{array}$ & 2.80552 & $\begin{array}{l}\text { Hydrogen } \\
\text { Bond }\end{array}$ & $\begin{array}{l}\text { Conventional } \\
\text { Hydrogen } \\
\text { Bond } \\
\end{array}$ & H-Donor & $\begin{array}{c}\text { H- } \\
\text { Acceptor }\end{array}$ \\
\hline & & $\begin{array}{l}\text { :LIG1:H - } \\
: \text { LIG1:O }\end{array}$ & 2.36001 & $\begin{array}{l}\text { Hydrogen } \\
\text { Bond }\end{array}$ & $\begin{array}{l}\text { Conventional } \\
\text { Hydrogen } \\
\text { Bond } \\
\end{array}$ & H-Donor & $\begin{array}{c}\text { H- } \\
\text { Acceptor }\end{array}$ \\
\hline & & $\begin{array}{c}\text { B:GLN241:HE21 } \\
- \text { :LIG1:H }\end{array}$ & 2.05135 & Unfavorable & $\begin{array}{l}\text { Unfavorable } \\
\text { Donor- } \\
\text { Donor }\end{array}$ & H-Donor & H-Donor \\
\hline
\end{tabular}

\begin{abstract}
Kondisi stres oksidatif, peningkatan kadar glukosa darah, peningkatan lipopolisakarida, dan tingginya jumlah sitokin pro-inflamasi dari reaksi AGE-RAGE merupakan beberapa faktor yang dapat memicu terbentuknya ekspresi Cyclooxygenase 2 (COX2). COX-2 juga dikenal sebagai prostaglandin (PG) sintase yang memiliki peran dalam proses sintesis enzim $\mathrm{PGE}_{2}$ dari asam arakidonat. COX2 diaktivasi selama terjadi inflamasi dan mudah teraktivasi oleh beberapa aktivator yaitu sitokin pro-inflamasi, faktor pertumbuhan, promotor tumor, aktivasi PKC, dan stres oksidatif (Retailleau et al. 2010).
\end{abstract}

Prostaglandin menginduksi fungsi fisiologis sel dalam jumlah besar kondisi patologis termasuk inflamasi jaringan (Kawahara, Hohjoh, Inazumi, Tsuchiya, \& Sugimoto, 2015). Kawahara et al. (2015) melaporkan enzim PGE2 yang merupakan produk dari COX-2 terhadap kondisi Diabetes Melitus Tipe 2. Kondisi ini menyebabkan inflamasi pada jaringan pulau Langerhans dan menghambat sekresi insulin.

Asam kuinat memiliki peran sebagai inhibitor COX-2 dapat menurunkan aktivasi NF$\kappa \mathrm{B}, \mathrm{PKC}$, dan p38 MAPK yang berperan dalam kondisi hiperglikemia yang diinduksi oleh COX2. Peranan jalur mekanisme COX-2 terkait regulasi kondisi hiperglikemia merupakan jalur mekanisme yang saling terkait (Radi 2012; Gao et al. 2014).
Interaksi COX-2 dan asam kuinat menyebabkan faktor pembentuk COX-2 pada sel target menjadi lebih sedikit karena beberapa ikatan pada sisi aktif. Kinerja asam kuinat akan menghambat kinerja COX-2 hal ini terbukti dengan adanya 11 residu asam amino yang berikatan dengan asam kuinat. Sel target yang mengalami dampak akibat reaksi inflamasi, dan produksi COX-2 yaitu endotel pada jaringan vaskular (Robertson \& Harmon 2006; Xie et al. 2006; Shanmugam, Gonzalo, \& Natarajan 2004).

\section{Simpulan dan Saran}

Asam kuinat memiliki potensi sebagai terapi anti-inflamasi COX-2 yang digambarkan dengan interaksi asam kuinat dengan 11 residu asam amnio. Kesebelas residu asam amino terbagi kedalam protein domain A (GLU140, ASN144, SER143, dan TRP139) dan protein domain B (GLU236, THR237, LYS333, GLN241, GLN330, PHE329, dan LEU238). Ikatan yang terbentuk ada ikatan hidrogen yang memungkinkan terjadinya ikatan yang kuat, dengan energi sebesar $-198.95 \mathrm{cal} / \mathrm{mol}$. Sehingga memiliki potensi menghambat kinerja COX-2 untuk memproduksi prostaglandin selama inflamasi. Perlu dilakukan penelitian secara in vitro untuk menguji kinerja asam kuinat terhadap COX-2. 


\section{Ucapan Terima Kasih}

Ucapan terima kasih kepada Ferry Yulianto yang telah menyediakan fasilitas selama penelitian berlangsung.

\section{Daftar Pustaka}

Aziz, T. 2009. Pengaruh Pelarut Heksana Dan Etanol, Volume Pelarut, Dan Waktu Ekstraksi Terhadap Hasil Ekstraksi Minyak Kopi. 16(1), 8.

Bare, Y., \& Fatchiyah, F. 2018. Profil Protein pada Organ Tikus (Rattus norvegicus) Model Diabetes Melitus Tipe 2 (DMT2). Biota, 11(1), 1-12. https://doi.org/10.20414/jb.v11i1.95

Bare, Y., Marhendra, A., Sasase, T., \& Fatchiyah, F. 2018. Differential Expression of IL-10 Gene and Protein in Target Tissues of Rattus Norvegicus Strain Wistar Model Type 2 Diabetes Mellitus (T2DM). Acta Informatica Medica, 26(2), 87. https://doi.org/10.5455/aim.2018.26.87-92

Chaudhury, A., Duvoor, C., Reddy Dendi, V. S., Kraleti, S., Chada, A., Ravilla, R., Mirza, W. 2017. Clinical Review of Antidiabetic Drugs: Implications for Type 2 Diabetes Mellitus Management. Frontiers in Endocrinology, https://doi.org/10.3389/fendo.2017.00006

Chen, L., Deng, H., Cui, H., Fang, J., Zuo, Z., Deng, J., ... Zhao, L. 2018. Inflammatory responses and inflammation-associated diseases in organs. Oncotarget, https://doi.org/10.18632/oncotarget.23208

Coussens, L. M., \& Werb, Z. 2002. Inflammation and cancer. Nature, 420(6917), 860-867. https://doi.org/10.1038/nature01322

Farhaty, N. 2016. Tinjauan Kimia Dan Aspek Farmakologi Senyawa Asam Klorogenat Pada Biji Kopi: Review. 14 https://doi.org/10.24198/jf.v14i1.10769

Gao, Z., Zhang, H., Liu, J., Lau, C. W., Liu, P., Chen, Z Y., ... Huang, Y. 2014. Cyclooxygenase-2dependent oxidative stress mediates palmitateinduced impairment of endothelium-dependent relaxations in mouse arteries. Biochemical Pharmacology, 91(4), 474-482. https://doi.org/10.1016/j.bcp.2014.08.009

Higdon, J. V., \& Frei, B. 2006. Coffee and Health: A Review of Recent Human Research. Critical Reviews in Food Science and Nutrition, 46(2), 101-123. https://doi.org/10.1080/10408390500400009

Inbathamizh, L., \& Padmini, E. 2013. QUINIC ACID AS A POTENT DRUG CANDIDATE FOR PROSTATE CANCER - A COMPARATIVE PHARMACOKINETIC APPROACH. 6(4), 7. https://doi.org/10.1111/cbdd. 12498

Kawahara, K., Hohjoh, H., Inazumi, T., Tsuchiya, S., \& Sugimoto, Y. 2015. Prostaglandin E2-induced inflammation: Relevance of prostaglandin e receptors. Biochimica et Biophysica Acta Molecular and Cell Biology of Lipids, 1851(4), 414-421. https://doi.org/10.1016/j.bbalip.2014.07.008

Kellogg, A., Pop-Busui, R., \& Cheng, H. T. 2008. Cyclooxygenase-2 Pathway as a Potential Therapeutic Target in Diabetic Peripheral Neuropathy. Current Drug Targets, 9(1), 68-76. https://doi.org/10.2174/138945008783431691

Kesuma, D., Siswandono, S., Purwanto, B. T., \& Hardjono, S. (2018). Uji in silico Aktivitas Sitotoksik dan Toksisitas Senyawa Turunan N-(Benzoil)-N'feniltiourea Sebagai Calon Obat Antikanker.
JPSCR : Journal of Pharmaceutical Science and Clinical Research, 3(1), 1. https://doi.org/10.20961/jpscr.v3i1.16266

Libby, P. 2006. Inflammation and cardiovascular disease mechanisms. The American Journal of Clinical Nutrition, $\quad 83(2), \quad 456 \mathrm{~S}-460 \mathrm{~S}$ https://doi.org/10.1093/ajcn/83.2.456S

Libby, P. 2013. History of Discovery: Inflammation in Atherosclerosis. 15 https://doi.org/10.1161/ATVBAHA. 108.179705.

Lipinski, C. A., Lombardo, F., Dominy, B. W., \& Feeney, F. J. 1997. Experimental and computational approaches to estimate solubility and permeability in drug discovery and development settings. Advanced Drug Delivery Reviews, 23, 3-25. https://doi.org/10.1016/S0169409X(96)00423-1

Medzhitov, R. 2010. Inflammation 2010: New Adventures of an Old Flame. Cell, 140(6), 771-776. https://doi.org/10.1016/j.cell.2010.03.006

Radi, Z. A. 2012. Comparative Pathophysiology and Toxicology of Cyclooxygenases. In Comparative Pathophysiology and Toxicology of Cyclooxygenases. https://doi.org/10.1002/9781118351918

Regulski, M., Piotrowska-Kempisty, H., Prukała, W., Dutkiewicz, Z., Regulska, K., Stanisz, B., \& Murias, M. 2018. Synthesis, in vitro and in silico evaluation of novel trans -stilbene analogues as potential COX-2 inhibitors. Bioorganic \& Medicinal Chemistry, 26(1), 141-151. https://doi.org/10.1016/j.bmc.2017.11.027

Retailleau, K., Belin De Chantemèle, E. J., Chanoine, S., Guihot, A. L., Vessières, E., Toutain, B., ... Henrion, D. 2010. Reactive oxygen species and cyclooxygenase 2-derived thromboxane A2 reduce angiotensin II type 2 receptor vasorelaxation in diabetic rat resistance arteries. Hypertension, 55(2), 339-344. https://doi.org/10.1161/HYPERTENSIONAHA.1 09.140236

Robertson, R. P., \& Harmon, J. S. 2006. Diabetes, glucose toxicity, and oxidative stress: A case of double jeopardy for the pancreatic islet?? Cell. Free Radical Biology and Medicine, 41(2), 177-184. https://doi.org/10.1016/j.freeradbiomed.2005.04.0 30

Santoso, B., \& Atmajaya, T. E. 2016. KAJIAN DOCKING SENYAWA 4-[(Z)-N-(4hidroksifenil)carboksimidoil]-2- metoksifenol $\begin{array}{lll}\text { SEBAGAI INHIBITOR } & \text { COX-2 }\end{array}$ MENGGUNAKAN PLANTS. 8.

Schröter, D., Neugart, S., Schreiner, M., Grune, T., Rohn, S., \& Ott, C. 2019. Amaranth's 2Caffeoylisocitric Acid-An Anti-Inflammatory Caffeic Acid Derivative That Impairs NF- $\mathrm{B}$ Signaling in LPS-Challenged RAW 264.7 Macrophages. Nutrients, 11(3), 571. https://doi.org/10.3390/nu11030571

Shanmugam, N., Gonzalo, I. T. G., \& Natarajan, R. 2004. Molecular Mechanisms of High Glucose-Induced Cyclooxygenase-2 Expression in Monocytes. Diabetes, 53(3), 795-802. https://doi.org/10.2337/diabetes.53.3.795

Shi, H., Dong, L., Jiang, J., Zhao, J., Zhao, G., Dang, X., ... Jia, M. 2013. Chlorogenic acid reduces liver inflammation and fibrosis through inhibition of toll-like receptor 4 signaling pathway. Toxicology, 303, 107-114. https://doi.org/10.1016/j.tox.2012.10.025

Xie, Y., Kang, X., Ackerman, W. E., Belury, M. A., Koster, C., Rovin, B. H., ... Kniss, D. A. 2006. Differentiation-dependent regulation of the cyclooxygenase cascade during adipogenesis suggests a complex role for prostaglandins. 


\section{Prediksi Asam Kuinat Sebagai Anti-Inflamasi}

Diabetes, Obesity and Metabolism, 8(1), 83-93. https://doi.org/10.1111/j.1463-1326.2005.00472.x Yusianto, \& Nugroho, D. 2014. Physical and Flavor Profiles of Arabica Coffee as Affected by Cherry Storage Before Pulping. Pelita Perkebunan (a Coffee and Cocoa Research Journal), 30(2), 137158.https://doi.org/10.22302/iccri.jur.pelitaperkeb unan.v30i2.7
Zhang, C., Maddelein, M.-L., Wai-Yin Sun, R., Gornitzka, H., Cuvillier, O., \& Hemmert, C. 2018. Pharmacomodulation on Gold-NHC complexes for anticancer applications - is lipophilicity the key point? European Journal of Medicinal Chemistry, 157, 320-332. https://doi.org/10.1016/j.ejmech.2018.07.070 